\title{
Japanese bureaucracy reforms may only pierce skin deep
}

Tokyo. The Japanese government's much vaunted plans for a radical reform of its semi-government organizations (tokushu hojin), some of which run much of the government's research and development activities, has turned into a feeble reorganization of only a handful of such bodies.

At present, there are 92 tokushu hojin under various ministries and agencies, responsible for spending more than $¥ 4,000$ billion (US $\$ 40$ billion) a year in taxpayers' money. Their proposed reform is a key policy of the administration of Prime Minister Tomiichi Murayama.

The reform is also controversial. Only a few weeks ago, a senior official at the Science and Technology Agency (STA) lost his job after resisting calls for reform by Makiko Tanaka, the cabinet member who heads the agency (see Nature 373, 177; 1995). But now that the plans have been released, it is difficult to see what all the fuss was about.

The STA oversees six tokushu hojin. These include several large research and development organizations, such as the Institute of Physical and Chemical Research, the National Space Development Agency, the Power Reactor and Nuclear Fuel Corporation and the Japan Atomic Energy Research Institute.

But these will be left untouched. The only change for the STA will be the 'merger' of two much smaller organizations, the Research Development Corporation of Japan (JRDC) and the Japan Information Center of Science and Technology (JICST).

There is no overlap between the activities of these two bodies. JICST provides (and in some cases sells) information services on Japanese science and technology, and maintains part of the government's computer network system linking research organizations in Japan and overseas.

JRDC supports the development of technology in the government sector and its transfer to industry. It is perhaps best known for its ERATO (Exploratory Research for Advanced Technology) programme which provides large grants to joint teams of young researchers from government institutes, universities and industry.

JRDC and JICST officials are bemused by the merger. A JRDC official says that until December they were under the strong impression that JICST would be privatized, had been discussed for many years.

JRDC was until recently in the same building as JICST in central Tokyo. But it moved last year to Kawaguchi city in the northwest suburbs of Tokyo as part of a government policy of decentralization. JICST, on the other hand, was about to move to another office in central Tokyo as part of its (now cancelled) privatization.
According to one JRDC official, fax messages are "flying back and forth" between JICST, JRDC and STA to establish what the merger means. But he says that his organization has been assured by the STA that none of its programmes will be affected. Indeed, past experience suggests that the merger will merely result in a reshuffling of staff, with few (if any) redundancies.

An official at one of the organizations says that other larger tokushu hojin under STA may have been left untouched despite Tanaka's call for reform - because Murayama, a socialist, wanted to avoid the labour disputes that would inevitably be involved in a major reorganization. He says the combination of Murayama and Tanaka, an outspoken member of the right-wing Liberal Democratic Party, has caused "great confusion" in the agency's reform plans.

Changes are also relatively minor in other science-related ministries. The New Energy and Industrial Technology Organization (NEDO), which administers most of the research and development projects of the Ministry of International Trade and Industry (MITI), will be merged with MITI's Coal Mining Areas Restoration Agency.

But NEDO already has a section that deals with the problems of land subsidence caused by collapse of old coal mine shafts. The agency will therefore be absorbed into NEDO without any disruption of NEDO's prime purpose, namely funding research and development in new technologies.

Indeed, most of the reform plan consists of such mergers. In total, 14 tokushu hojin will be merged into seven. Only one body the Institute of Social Security Research will be abolished. And even that will not really disappear, as it is to be incorporated into a reorganization of seven national research institutes under the Ministry of Health and Welfare (MHW), from which will emerge six new health and medical research institutes.

The main aim of the MHW reorganization is to bring together institutes with common or related roles. For example, four separate institutes involved in public policy research, covering topics such as public health and population problems, will be combined into two.

Public criticism of the failure of the reform plan to go as far as some feel necessary has further weakened the coalition government, already being torn apart by a split within the Social Democratic Party, headed by the prime minister. But administrative reform is likely to be continued by future governments, and the tokushu hojin may therefore still experience more attacks.

David Swinbanks

\section{ESO chief pledges to fight Chilean telescope ruling}

Garching. Riccardo Giacconi, director of the European Southern Observatory (ESO), said last week that he plans to defy a court order to stop building work on the observatory's next big project, the Very Large Telescope (VLT), sited at Mount Paranal in northern Chile, unless directly threatened by the Chilean government.

If such a threat materializes, said Giacconi, he plans to take the government to international court for breach of contract. His pledge reflects frustration that, despite two years of apparently successful negotiations with the Chilean authorities, a bitter legal dispute over the ownership of the land on which it is to be build remains unresolved (see Nature 368, 676; 1994).

The VLT, which will be the world's largest optical telescope when it is completed, is expected to cost around DM463 million

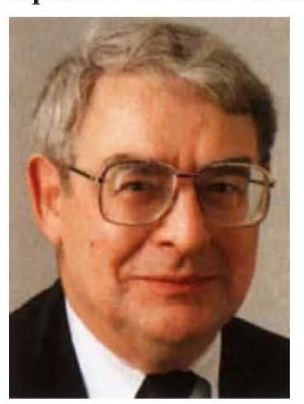

Giacconi: prepared to fight government
(US\$303 million). But its future continues to be threatened by the claims of a local family to the land, which was given to ESO by the government in 1988 .

Two years ago the family began legal action to secure recognition of its claim. But ESO has always maintained that, as an international organization, it has immunity from local law. It has entered a chain of appeals and counter appeals with the Chilean courts, while the government, with which ESO has an agreement dating back to 1964 , has stood aside.

Last spring, ESO stopped construction work after an injunction was brought against the construction company Skanska-Belfi. Giacconi says that this was a very expensive gesture of goodwill which will not happen again. "It would take the police or the army to stop us now," he says.

A year ago, frustrated by the endless problems in Chile, ESO was considering transferring the location of the VLT to an alternative site in Namibia. But investment at Mount Paranal is now too great for this still to be an option.

But ESO does have some cause to feel optimistic. Australian scientists have asked their government to become an ESO member state in order to gain access to the VLT facility. The extra money from expanded membership would allow ESO to restore the VLT interferometry for completion in the year 2000 (it has been delayed to save money). 